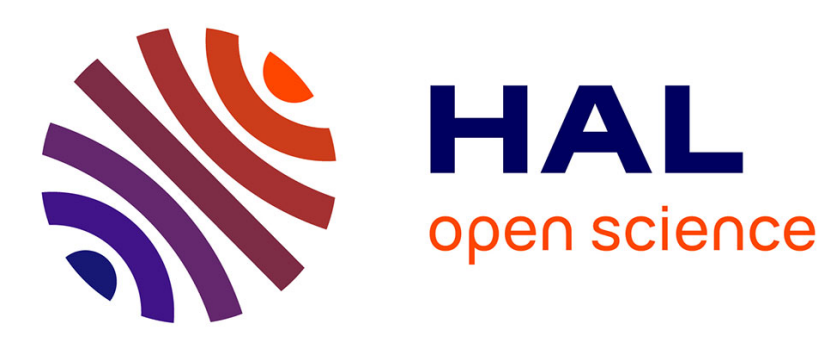

\title{
New Approach to the Study of City Planning and Domestic Dwellings in the Ancient Near East
}

\author{
Christophe Benech
}

\section{To cite this version:}

Christophe Benech. New Approach to the Study of City Planning and Domestic Dwellings in the Ancient Near East. Archaeological Prospection, 2007, 14, pp 87-103. 10.1002/arp.306 . hal-00412125

\section{HAL Id: hal-00412125 \\ https://hal.science/hal-00412125}

Submitted on 3 Oct 2009

HAL is a multi-disciplinary open access archive for the deposit and dissemination of scientific research documents, whether they are published or not. The documents may come from teaching and research institutions in France or abroad, or from public or private research centers.
L'archive ouverte pluridisciplinaire HAL, est destinée au dépôt et à la diffusion de documents scientifiques de niveau recherche, publiés ou non, émanant des établissements d'enseignement et de recherche français ou étrangers, des laboratoires publics ou privés. 


\title{
New Approach to the Study of City Planning and Domestic Dwellings in the Ancient Near East
}

\author{
Christophe Benech \\ Maison de l'Orient et de la Méditerranée, UMR 5133 Archéorient, 7, rue Raulin, 69007 Lyon, France \\ Christophe.benech@mom.fr
}

\begin{abstract}
This paper presents the results of a magnetic survey on the Hellenistic and Roman site of Doura-Europos in Syria. The interpretation of the magnetic data is based on an original approach by considering the use of space in a domestic unit. This type of study has been developed for sociological research but is adapted to the information carried within geophysical data. After a brief presentation of the role of geophysical methods for the study of city planning, the most important components of the 'space syntax' will be presented and applied to two blocks of Doura-Europos, one that has been excavated in the twentieth century by the Yale University and another surveyed using the magnetic method.
\end{abstract}

Key words: magnetic survey; city planning; domestic unit; space syntax; Doura-Europos; ancient Near East

Si tu ne sais pas répondre à la question posée, demande toi si tu ne peux pas répondre a' une autre question qu'on a oublié de te poser (If you cannot answer a question, ask yourself whether you are able to answer another question they forgot to ask you) (Hesse, 1999)

\section{INTRODUCTION}

The different geophysical methods available today allow the collection of very detailed information about archaeological sites and their environment. However, these spectacular results are still often confronted with scepticism and even with disbelief by archaeologists (Hesse, 1999; Gaffney and Gater, 2005) because of the problem of interpretation and of integration of geophysical data into archaeological maps. This is a subject that has been discussed many times and interesting solutions have been proposed (see Neubauer, 2004).

A geophysical map is not an archaeological plan and it would be utopian to expect the precision of a topographical plan of an excavated area the base map from which archaeologists work from it. These two sources provide very different types of information, which cannot be treated in the same way. If we treat a geophysical map in the same way as an archaeological plan, the result will always be less reliable, and the essential and original contribution of the geophysical data will be neglected. It is more fruitful to focus on their complementary nature in order to provide a new vision of the archaeological site and renew thematic and methodological approaches.

For better utilization of the geophysical map in archaeology, geophysicists and archaeologists have to hold a dialogue concerning (i) the type of information that can enhance knowledge of the archaeological site and (ii) the development of a new approach to archaeological issues arising from documentation based on architecture, stratigraphy and, more generally, the spatial organization of archaeological remains. This is the sort of process is developed here, in the particular case of city planning and households in the ancient Near East. The present study is based on geophysical surveys carried out at the site of Doura-Europos (Syria), where extensive documentation concerning urbanism and households exists. In this case, data from a magnetic survey are used, but the more general discussion could extend to other geophysical methods. 
THE STUDY OF HELLENISTIC AND

ROMAN URBANISM IN ARCHAEOLOGY

The study of city planning, and more generally urbanism, is best undertaken by an extensive archaeological survey, the aim of which is to recognize the urban space as completely as possible. Hellenistic cities of the Near East adopted the same the city planning, which is known as the 'Hippodamian plan'. This concept, brought by Macedonian settlers, is based on the parcelling of rectangular blocks separated by orthogonal streets of the same width (Figure 1). These blocks were also divided into dwelling units of the same size. The dimensions of the blocks, their inner division and the width of the streets varied from one site to another but theoretically are supposed to be the same for a given city (Martin, 1974). The Hippodamian plan is therefore taken to illustrate a particularly egalitarian - restrained and austere - division of the urban space, as opposed to the more monumental and hierarchical urbanism developed by the Romans.

Until recently, the method used to study the urban space was almost the same for all the archaeological sites of the Near East, and it has also been applied in Doura-Europos (Figure 2). Wide-area excavation at the beginning of the twentieth century at some ancient cities resulted in a rich archaeological documentation. Some blocks were completely excavated, and the entire town plan was reconstructed by digging up the angles of non-excavated blocks (when it was possible, as in Doura-Europos) or by extrapolation, reproducing on the whole surface of the city the module of reference identified in excavated blocks. Those early excavations were focused on 'prestigious' monuments: administrative or religious buildings, rather than domestic dwellings. Apart from some sites such as Olynthus (Greece), Delos (Greece) and Doura-Europos, domestic dwellings were usually illustrated by the excavation of a 'standard block' which was supposed to represent all the households of the city.

Therefore, this method only allowed for the reconstitution of a schematic plan of the city. It may be possible in this way to illustrate the theoretical concept used for the organization of the city, but it cannot help us understand the real administration of the urban space - and its evolution.

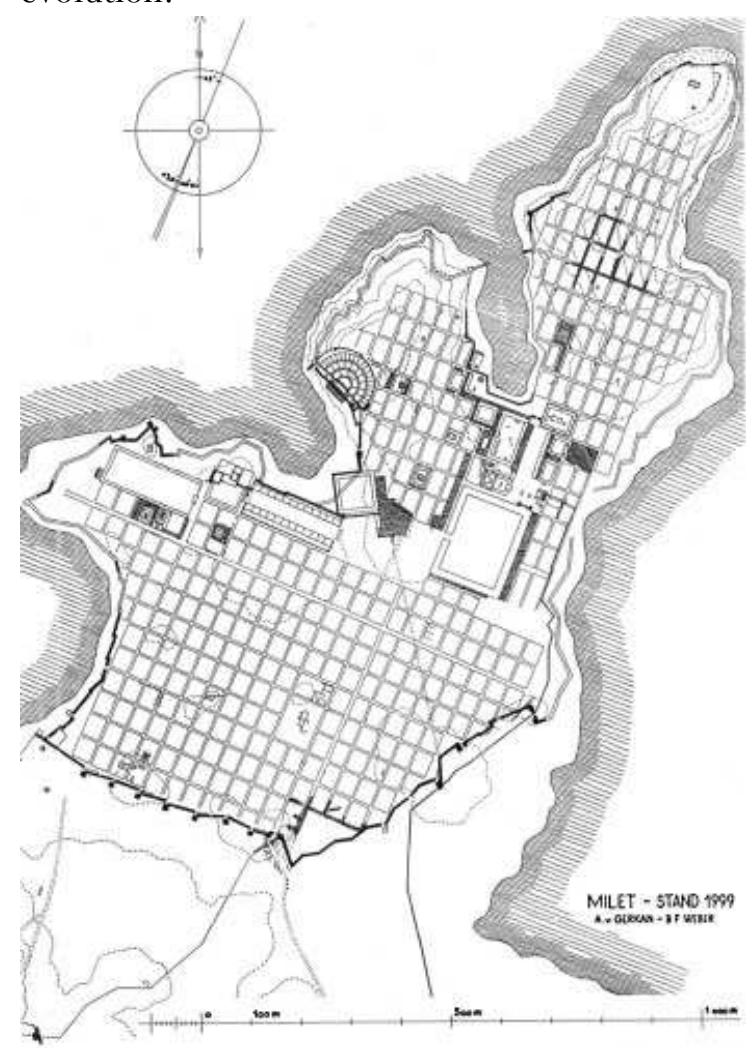

Figure 1. Hippodamian plan of Miletus (Turkey) known as one of the oldest city plans of this type. It comprises two different modules of blocks: $51.60 \mathrm{~m} \times 29.50 \mathrm{~m}$ for the southern part, and $20.75 \mathrm{~m} \times 17.70 \mathrm{~m}$ for the northeastern part.

For reasons of cost, and also because of the emergence of a better methodology of research and the question of conservation of excavated remains, such large-scale excavations are no longer undertaken. Consequently, current research, suffers because of a drastic lack of new data. Modern excavations, more punctual but also more rigorous, yield important data about the life of the city, but do not permit us to refine the simplified scheme of the organization of the urban space. Geophysical survey is currently the only non-destructive technique for obtaining new data. The results can be more interesting than the data obtained hitherto, because if the environmental conditions are good enough the whole urban layout of a city can be investigated. Numerous such studies have been made or are still in progress (e.g. 
Becker et al., 1993; Gaborit et al., 1999; Groh, 2003; Schmidt-Colinet and Plattner, 2001).

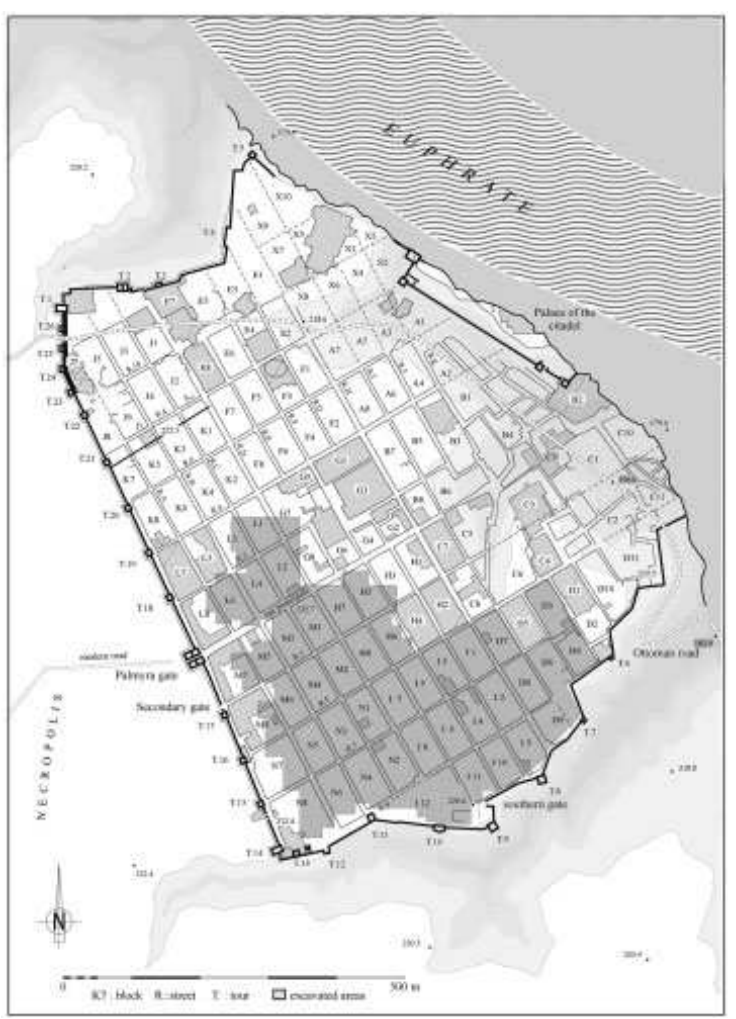

Figure 2. Plan of Doura-Europos (Syria) (from Rostovtzeff, 1939 and redrawn by H. David). The area surveyed is in dark grey and the excavated areas are shown in middle grey.

These surveys have helped to highlight the main characteristics of the urban space of different ancient cities, i.e.:

(i) limits of the city, fortifications, location of gateways;

(ii) main characteristics of the plan - length and orientation of the streets, block module;

(iii) differentiation between built and non-built areas;

(iv) differentiation between public and private areas;

(v) identification of the function of some buildings that have a typical plan.

These results are important in themselves but do not account for the richness of geophysical data, because only the most visual and the most readable information from the geophysical map is used. Mostly, it is at this step of the interpretation that dissent occurs between archaeologists and geophysicists, because the geophysical map lacks the precision of an archaeological plan despite its detailed information. The detailed interpretation of the geophysical map is normally limited to a 'line by line' restoration of visible geophysical anomalies; the result should be a noninterpretative drawing but this type of work reduces the coherence of built structures- it involves conscious choices and, moreover, unconscious choices.

Different experiences of the interpretation of geophysical data have shown that, whatever the type of reconstruction chosen, it can be applied only when the logic and the organization of the archaeological features being analyzed are clearly identified, and understood, by a more detailed interpretation (e.g., in the case of city planning and buildings, see Hesse, 1970; Groh et al., 2002).

A detailed interpretation must first of all be based on archaeological documentation of the site (if available) or from another site from the same period and with the same type of occupation. From this point of view, it is obvious that archaeological and geophysical approaches are closely linked: the work of the geophysicist does not end with the presentation of more or less detailed maps, and that of the archaeologist does not begin with the archaeological interpretation of this presentation. A new step may be suggested, departing from our conviction that every interpretative approach is linked to the problems posed by archaeology. By contrast, it is sometimes necessary to reorient the questions of the archaeologist, in order to analyse the geophysical data with the most appropriate method.

This type of approach is applied here to the households of the Near East Hellenistic city of Doura-Europos. 
DOURA-EUROPOS (SYRIA)

The site of Doura-Europos was discovered at the beginning of the twentieth century and was excavated by F. Cumont (1922-23), a French and American mission directed by $\mathrm{M}$. Rostovtzeff (Yale University), and since 1986 a French and Syrian mission directed by $\mathrm{P}$. Leriche (Centre National de la Recherche Scientifique).

Doura-Europos is located on the right bank of the River Euphrates on a limestone plateau at around $30 \mathrm{~m}$ above the river (Figures 2 and 3). The historical developments outlined below highlight the most important phases of the urban development of the site as they have been understood by successive archaeological excavations.

Founded at the end of the fourth century BC by the Macedonians, Doura-Europos was originally a military station. The concept of the city planning (and therefore the accession to the status of 'city'), began in the middle of the second century BC. About $133 \mathrm{BC}$, the city fell under Parthian

domination; by this date, only the sector of the agora and also some administrative and religious buildings had been completed. The new Parthian authorities continued the urban programme respecting the Hippodamian plan that had been established by the Macedonians. The dimensions of the blocks are on average 35 $\mathrm{m} \times 70 \mathrm{~m}$; the width of the streets is about $5 \mathrm{~m}$, except for the main streets, starting from the Palmyra gate, which reach about $10 \mathrm{~m}$. In AD 165 , the city was taken over by the Romans, and the city planning was subsequently greatly modified, mainly due to the installation of a military camp in the northern part of the city. The Romans constructed many buildings in this sector without taking the pre-existing Hippodamian plan into account. Finally, in AD 256, Doura-Europos was pillaged by the Sassanids and practically abandoned.

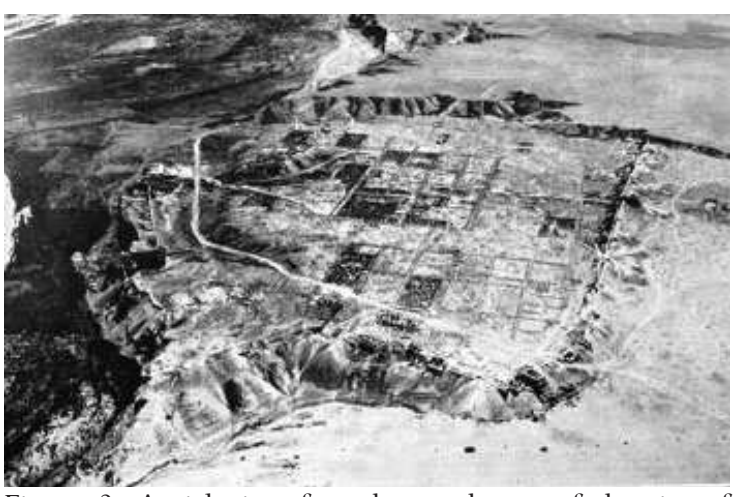

Figure 3. Aerial view fromthe south-east of the site of Doura-Europos.

Obviously, the geophysical map shows the last phase of more than four centuries of occupation i.e. the result of the evolution of the application of an urban theoretical concept: the Hippodamian plan.

\section{FIRST RESULTS WITH MAGNETIC} SURVEY

The magnetic survey of Doura-Europos was carried out with a caesium gradiometer, and the southern half of the site has been completely covered (Figures 2 and 4) (Benech, 2003).

Unlike the schematic plan established by the Yale expedition (1928-1937), the geophysical data record variations street width. In some cases the variation is considerable and indicates a hierarchical organization of the streets, probably linked to the circulation inside the city. Some of the main streets (particularly the ones starting from the Palmyra gate) conserved their original width, whereas others (probably those less frequently used) became narrower with time due to the encroachment of houses onto the public thoroughfare.

According to the results of the excavations, the Yale expedition suggested an internal division of the blocks into eight identical parcels, although this division is not really clear in the excavated blocks. The geophysical map clearly identifies some plans of houses that were already known from the excavations, and which fill exactly $1 / 8$ of the total area of the block (Figure 5). Not all blocks of Doura-Europos, however, have the 


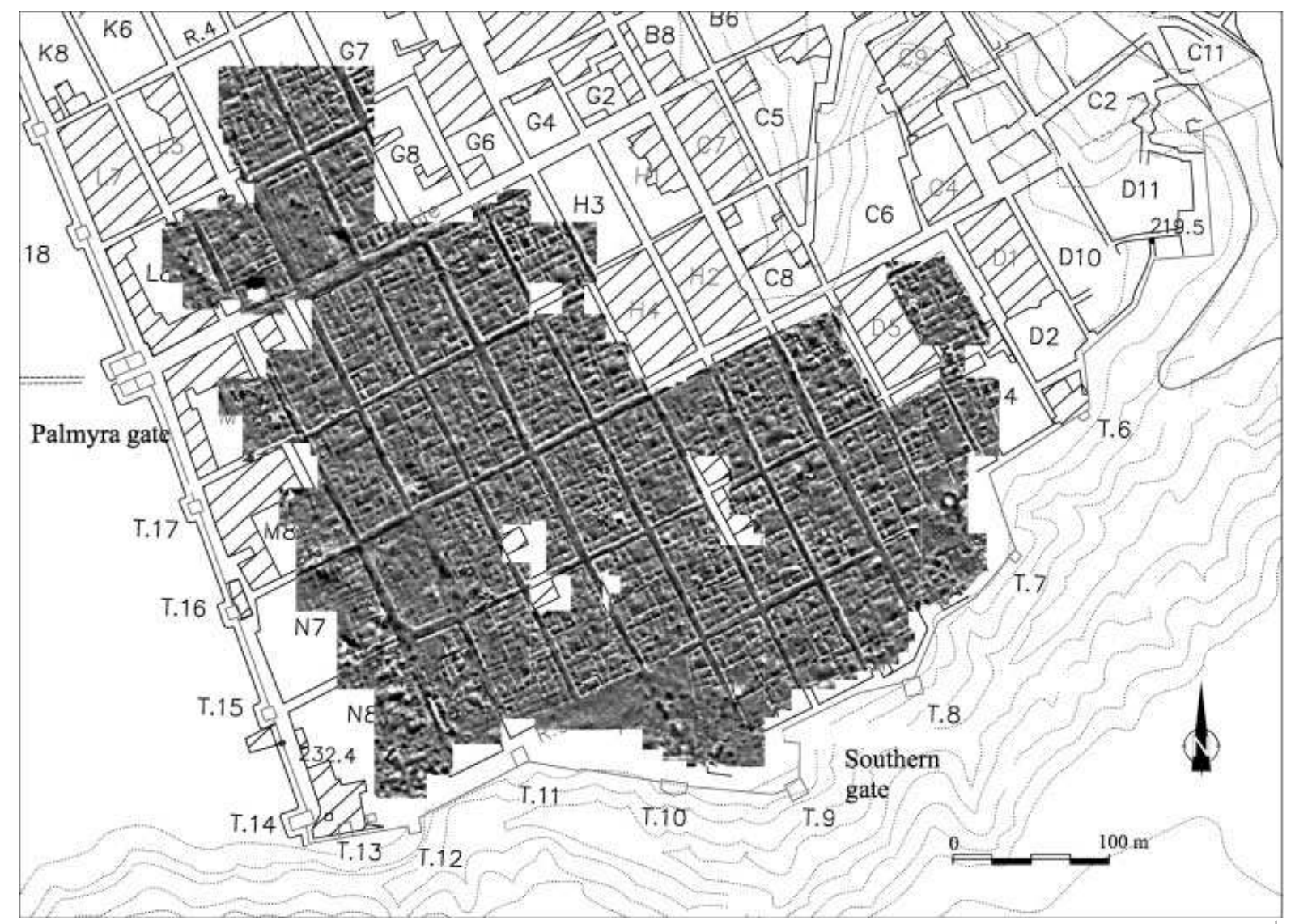

Figure 4. General magnetic map of the geophysical survey of the southern part of the site (minimum white $=-10 \mathrm{nT} \mathrm{m}^{-1}$ : maximum black $\left.=+10 \mathrm{nT} \mathrm{m}^{-1}\right)$. The magnetic survey has been carried out with a caesium gradiometer recording measurements every $0.20 \mathrm{~m}$ along profiles of $1 \mathrm{~m}$ apart.

same internal division: in the southern part of the city the geophysical map reveals two blocks (I 10 and I 11) that are divided into six parcels. This is the first time that the existence of two different types of division has been observed in a Hellenistic city of the Near East, but we do not know yet if they are contemporary. In block I 11, two of these parcels are free from construction, and different hypotheses may be advanced concerning their function: they could be gardens, stock areas or enclosures for animals, a notion which might be justified by the proximity of the southern gate of the city.

\section{THE STUDY OF DOMESTIC SPACE}

The excavations of Doura-Europos present a pronounced diversity of the ground plans of domestic houses. The geophysical maps, even if they are very clear, do not identify the plan of every house inside the blocks. There are always numerous ambiguities, in particular concerning the limits of the houses, the function of the different rooms and the circulation inside the house (to which may be added the problems of blocked doors (Figure 6) or partly ruined walls, which give the illusion of a passage on a geophysical map). These aspects are, of course, all easy to solve in excavation and play an important role in the study of the household following the traditional approach.

The study of individual households traditionally has been based on the classical literature available. However, written sources are of little value with respect to the archaeological data, which are mostly fragmentary. They describe a way of life very localized geographically, and leave the door open to misleading generalizations (for a critique of the use of classical sources see the introduction of Nevett, 1999).

Study of the household can be approached from 

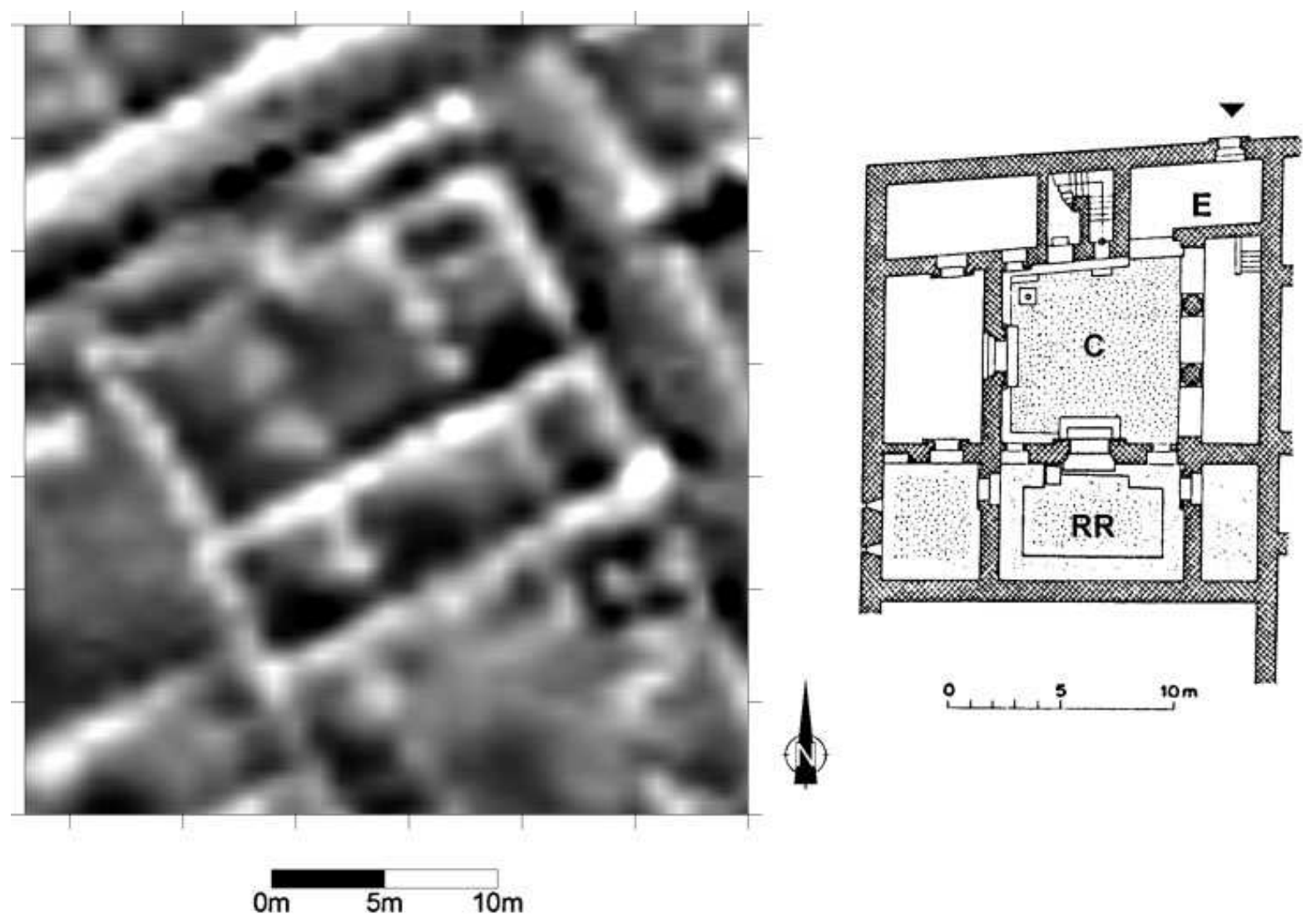

Figure 5. Comparison between the plan of an excavated house (from Hoepfner and Schwander,1986) and the plan of a house shown by geophysical survey (from block M4 - minimum white $=-10 \mathrm{nT} / \mathrm{m}$ : maximum black $=+10 \mathrm{nT} / \mathrm{m}$ ). The entrance is not on the same side of the block but there is a corridor, which means that the courtyard is not visible from the street. In the southern part of the house, there is the reception room, opened to the north, with two adjacent rooms. The eastern side of the house is covered but open to the courtyard and is the place of domestic activities such as cooking. This is a typical domestic unit of Doura-Europos, which occupies exactly $1 / 8$ of the surface of the block. (E, entrance; C, courtyard; RR, reception room).

another point of view, which is the use of space. This method has been used previously by archaeologists, in particular those working on the most ancient periods (Hodder and Orton, 1976; Renfrew, 1984). Their aim was to introduce methods of analysis developed in ethnology, sociology and anthropology (Rapoport, 1972; Levi-Strauss, 1993; Bourdieu, 2000). Important works have shown that the study of the use of domestic space is complementary to a more traditional architectural study (Kent, 1990a; Parker Pearson and Richards, 1994; Allison, 1999). Some of these studies are concerned with the Classical period (Jameson, 1990; Laurence and Wallace-Hadrill, 1997; Nevet 1999; Cahill,
2002) and they have yielded interesting, albeit at times somewhat fragmentary, results in accordance with the archaeological documentation available for the different sites that have been studied.

Sociologists B. Hillier and J. Hanson have shown that the organization of space may reflect the social, economic and cultural characteristics of a society. They developed the 'space syntax' method of analysis, which can be easily applied to geophysical maps (Hillier and Hanson, 1984; for a summary see Grahame, 1997). The geophysical map brings a new, continuous and homogeneous documentation to this domain, which can play an important role if the methodology is adapted to the nature of 
geophysical data. The archaeological studies cited above present the idea that it is the use of space that influences the record of archaeological materials (ceramics, objects, etc.) and their architectural elements - not the other way around (Kent, 1990b). Such an approach is interesting to apply to geophysical maps, even if it is necessarily limited to a study of the ground plan, which admittedly could be considered to be extremely restricted.

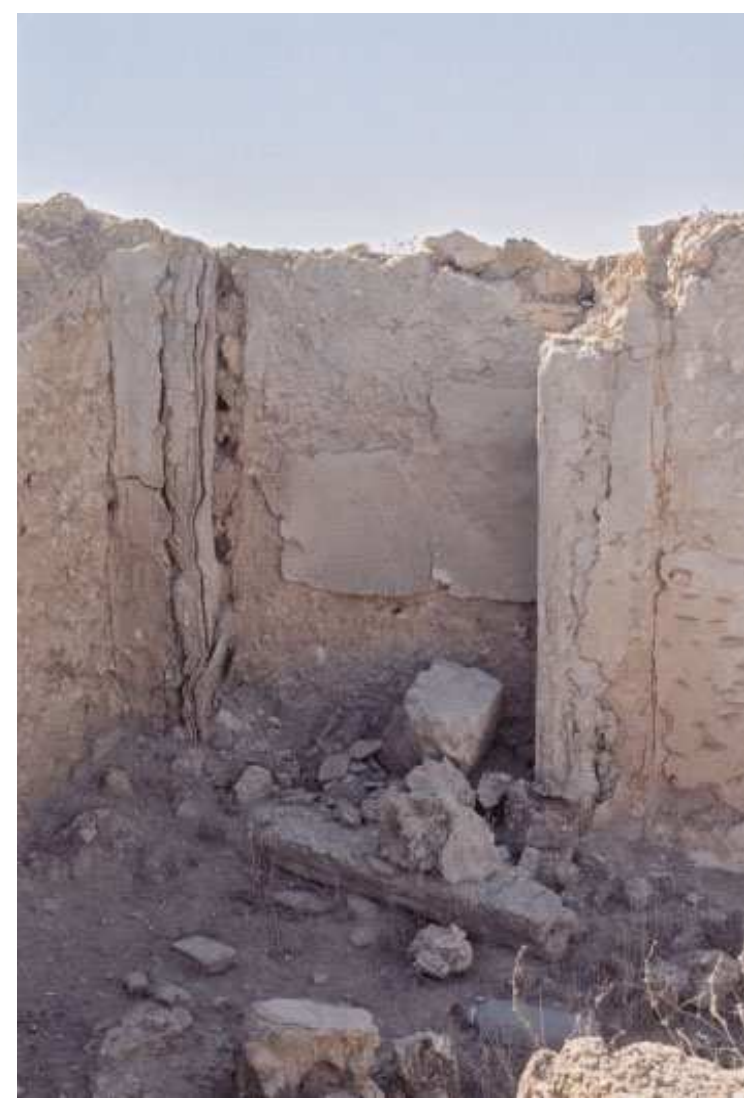

Figure 6. Example of a door blocked with mudbrick.

The chosen approach is to use as a starting point a plan delimiting all the spaces, and not from a plan locating the walls. Such a reconstruction is more accurate given the nature of geophysical data: it is very difficult indeed to restore the geometry of the walls with precision, to the same degree as that inherent in a plan derived from excavation. On the other hand, it is not hard to delimit surfaces. Moreover, the quality of a study of the use of space does not suffer from a certain error tolerance that is inevitable if we work from a geophysical map.
For the first time, this approach will be validated by a comparative study of two blocks of Doura-Europos, one completely excavated by the Yale mission, and another one surveyed with the caesium G-858 gradiometer. To fulfil this aim the main characteristics of a household are presented in order to understand the logic of the use of space in the houses of DouraEuropos.

MAIN CHARACTERISTICS OF DOURA-

EUROPOS HOUSES

The houses of Doura-Europos are organized around three main elements, the entrance (E), the courtyard (C) and what for present purposes will be referred to as 'the reception room' (RR) (Figure 5).

The entrance is normally an ' $\mathrm{L}$ ' shaped corridor leading to the courtyard, which generally is not visible from the street; but in the case of particularly small houses the entrance looks directly on to the courtyard. There may be more than one entrance, particularly if the house is large; there are also houses where a room is used as a shop, which has an independent entrance.

The open courtyard is, generally speaking, the main place of the house. It is the point from which circulation inside the house is organized, and it controls the access to most of the other rooms, and to the roof or the first floor, when one exists. It is the focal point of the main domestic activities (cooking).

The reception room is the most significant room from a social point of view. This room stands out from the rest by its comfort, architectural decoration and orientation: it is generally open to the north, to preserve a minimum of freshness inside the room. However, in the case of smaller houses, the position of the reception room may be different.

The space syntax suggested by Hillier and Hanson (1984) allows visualization of the organization of space inside the houses. Plans 
that look different may in fact have the same logic of organization. We have modified the scheme proposed by Hillier and Hanson: the circles on Figure 7, which represent individual rooms, are proportional to their surface areas, and the whole scheme is enclosed in a circle proportional to the total surface area of the house.
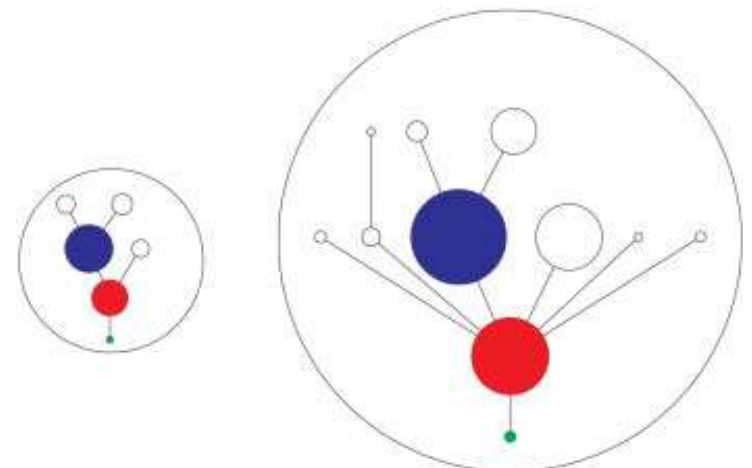

Figure 7. Scheme of houses 2 and 4 in block C7 (see Figure 9) following the space syntax of Hillier and Hanson (1984). We see here the articulation entrance (green), courtyard (red), reception room (blue), for this last one. The widest houses are first characterized by the greater number of rooms around the courtyard.

When using this scheme, account must be taken of ambiguities due to the interpretation of the magnetic maps:

(i) The circulation inside the house presents a problem: the passages between the rooms are not always clear. Partly ruined walls can be mistaken for an opening. In the case where archaeological structures are preserved on a very weak elevation, the magnetic signal of the stone block (gypsum most of the time), which constitutes a threshold, may be mistaken for the signal of a wall; in such cases, the opening is then practically undetectable.

(ii) The excavated blocks show a pronounced variation in the width of the walls (from $20 \mathrm{~cm}$ to more than $1 \mathrm{~m}$ ); the thinnest dividing walls are usually completely ruined and may not appear on the magnetic map.

(iii) Another difficulty concerns the delimitation of the different houses of the block. This question is all the more complex because transformations through time inside the house are frequently seen in Doura-Europos, mainly due to alterations caused by inheritance (Saliou, 1992) or by the purchase of rooms by neighbouring houses. Houses 4 and 6 of block C7 are highly complex examples of this, and clearly show the type of ambiguity that our study confronts (Figure 8). These houses are examplars of the division of a 'standard' size house (i.e. 1/8 of the surface of the block), which had a central courtyard and distribution of rooms around it. The identification of two different courtyards and two entrances would be obvious to an excavator, but not so on a magnetic map. Such an organization presumably would be interpreted as a unique house.

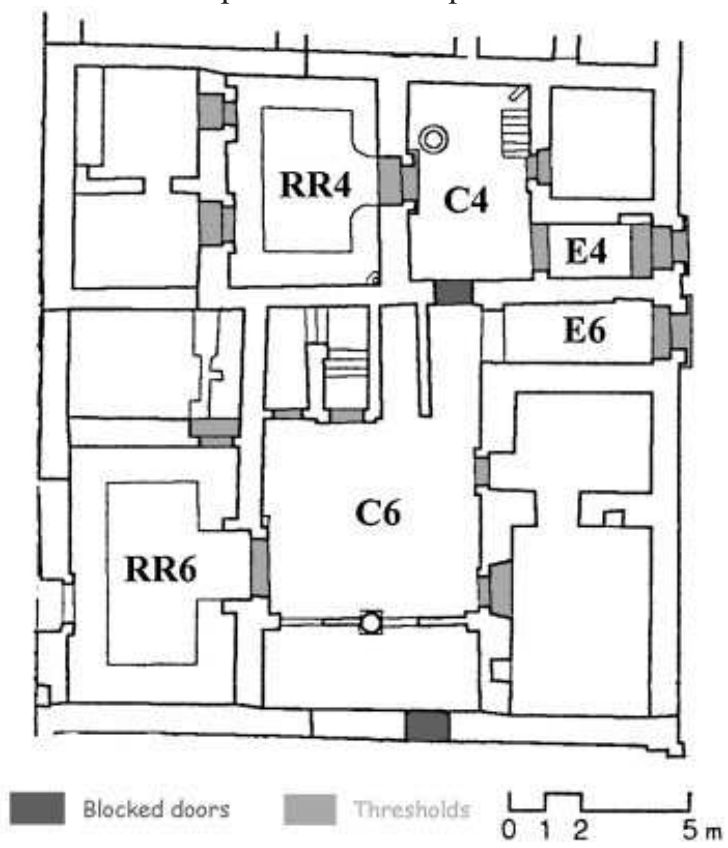

Figure 8. Plan of houses 4 and 6 in the bock C7 (see Figure 9). The total surface of both houses is equivalent to $1 / 8$ of the surface of the blocks, indicating that an original division has been divided into two dwelling units. Such an organization could appear as a single domestic unit on a geophysical map: only the two entrances suggests that there are two units, but even in this case the second entrance could interpreted as one associated with a shop.

These limitations necessitate an initial argument about the concept of space rather than about the use of space, but a statistical study may help to further the interpretation. Of course, it is impossible to present a reliable statistical analysis on the basis of a study of two blocks only, but the relevance of this application to an understanding of excavated and surveyed blocks 


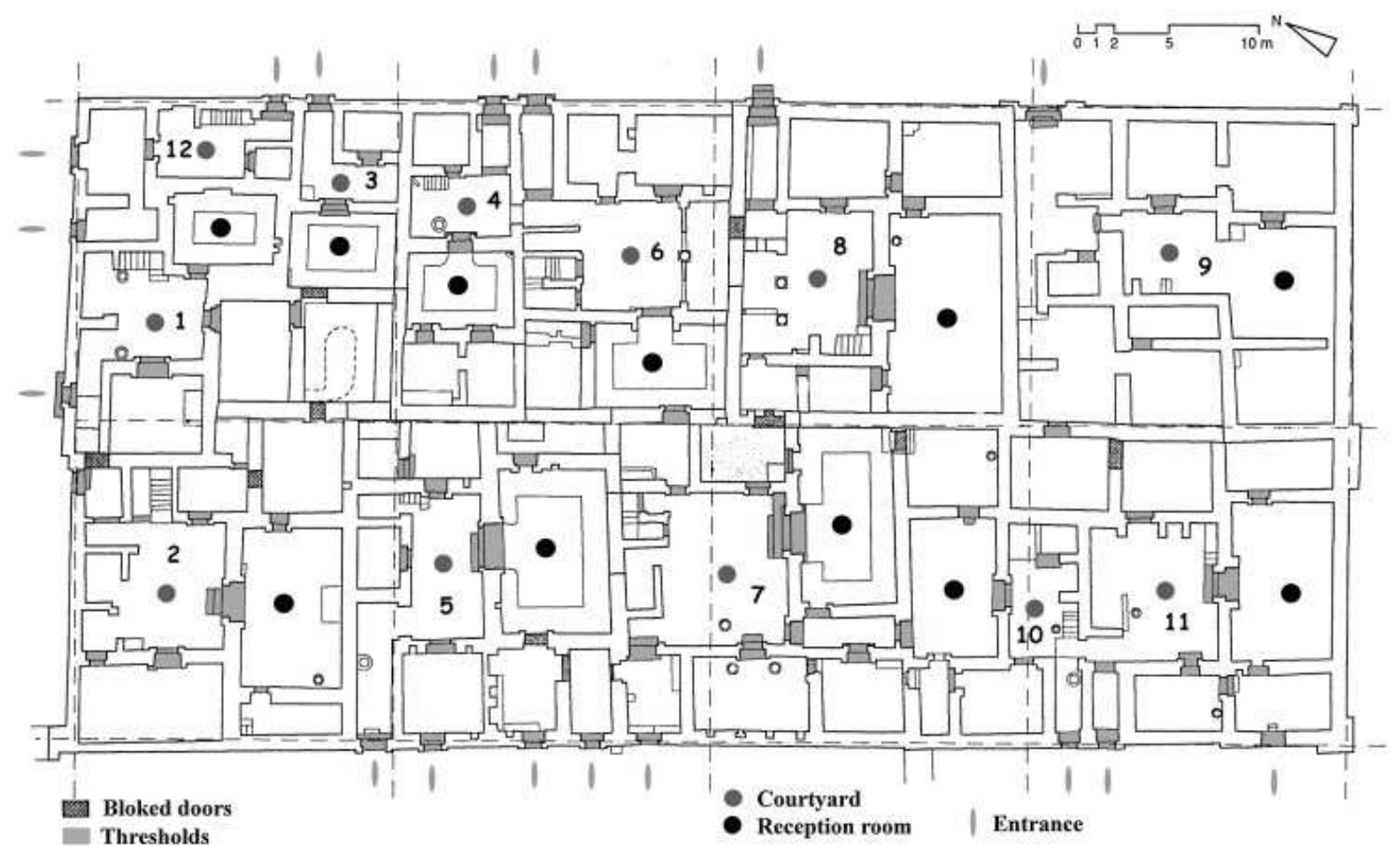

Figure 9. Plan of block C7 (from Saliou, 2005). The block comprises 11 dwelling units but there are 17 entrances, indicating the presence of shops with independent entrances.

clearly emerges, which enables a predictive model to be built that will facilitate the interpretation of geophysical maps and offer an original and new approach to the study of the household.

In archaeological publications, the terms 'house' and 'dwelling unit' are often synonymous. The term 'house' is used in the following interpretation when domestic units have been identified with certainty or with reference to the social functions of a private building; the term 'dwelling unit' will be used for units which potentially include rooms with nondomestic functions (shop, workshop, etc.).

\section{CASE STUDY I: BLOCK C7}

Block C7 is the only completely excavated block of Doura-Europos that comprises only domestic dwellings, i.e. no administrative or religious buildings (Figure 9) (Hopkins, 1934; Saliou, 2005). There are two other blocks of domestic dwellings, but they constitute particular cases because they comprise particularly large houses, which nearly (block D5) or entirely (D1) occupy the area of the block.

In its final state of occupation, block C7 contained 12 dwelling units, the limits of which no longer correspond to the original division. The entrance, the courtyard and the reception room are clearly identified for all units except for unit 9, where the location of the reception room is uncertain. The area of the dwelling units is extremely variable, from $54 \mathrm{~m}^{2}$ to 320 $\mathrm{m}^{2}$, which is far from the egalitarian division of the Hippodamian concept. Many uncertainties remain about the organization of the block, which was quickly excavated using the techniques current at the beginning of the twentieth century: neither its stratigraphy nor its chronology were recorded well. Some of the rooms continued in use in later periods, and it is difficult to establish their correct plan, even for the last phase of occupation (the plan of unit 9 is particularly doubtful).

There are 17 entrances for 12 dwelling units, hence the block may contain five shops. It is beyond the scope of this paper to apply the space syntax approach to each dwelling unit. 
(a)

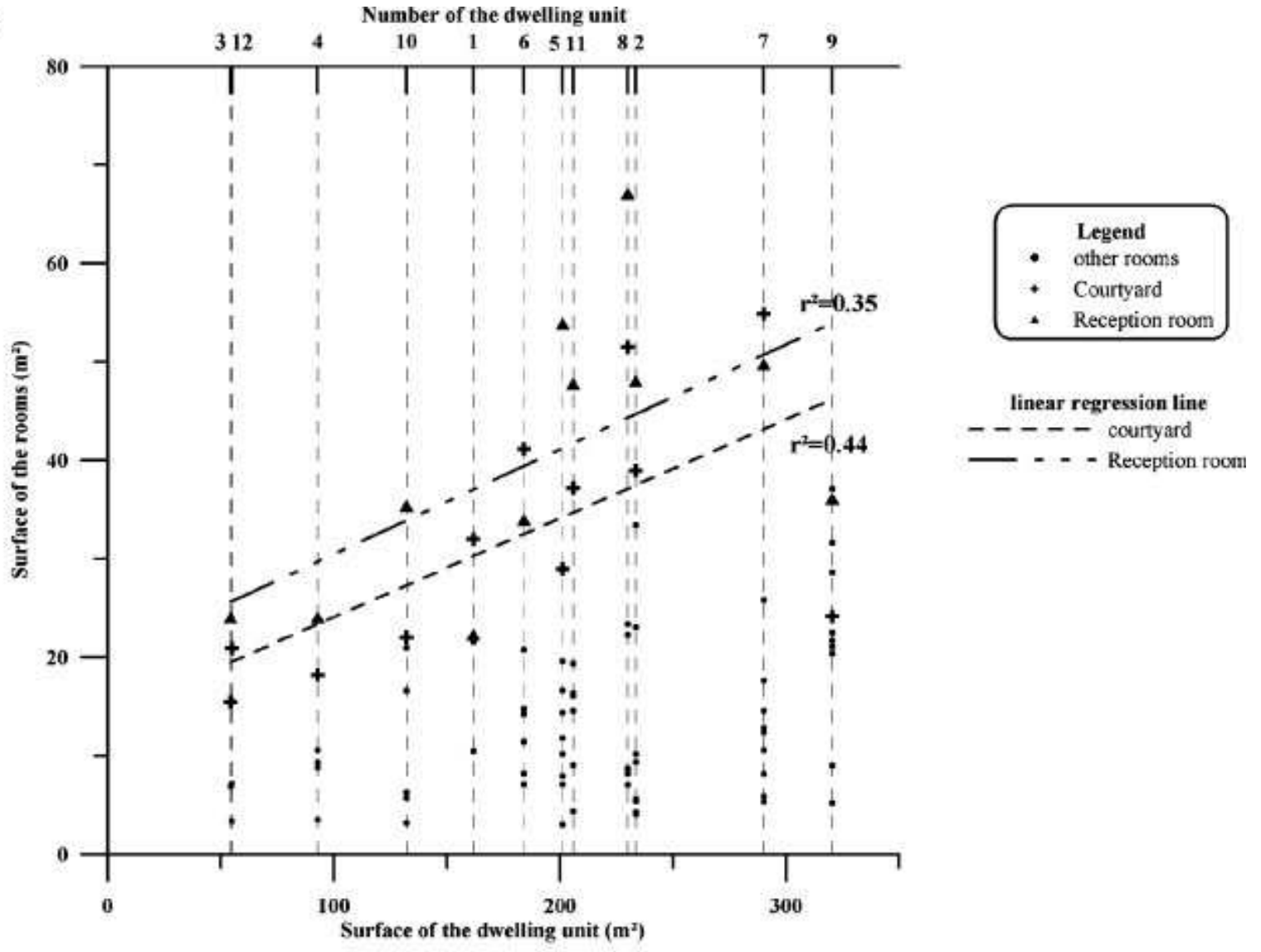

(b)

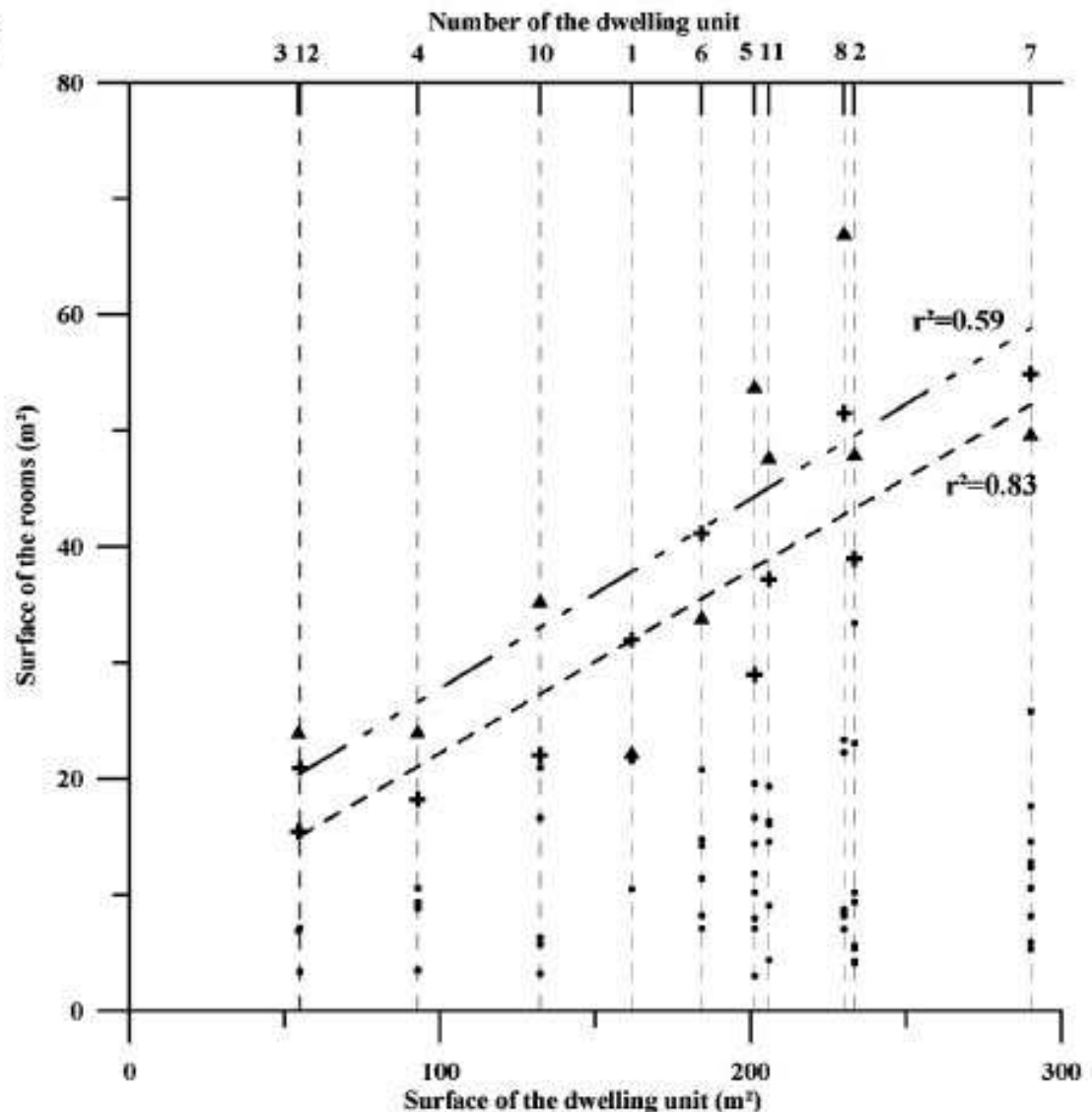

Figure 10. Distribution of the surface of the rooms for each domestic unit: (a) block C7; (b) block C7 without unit 9; (c) block M2; (d) block M2 with unit 2 divided into domestic units. 


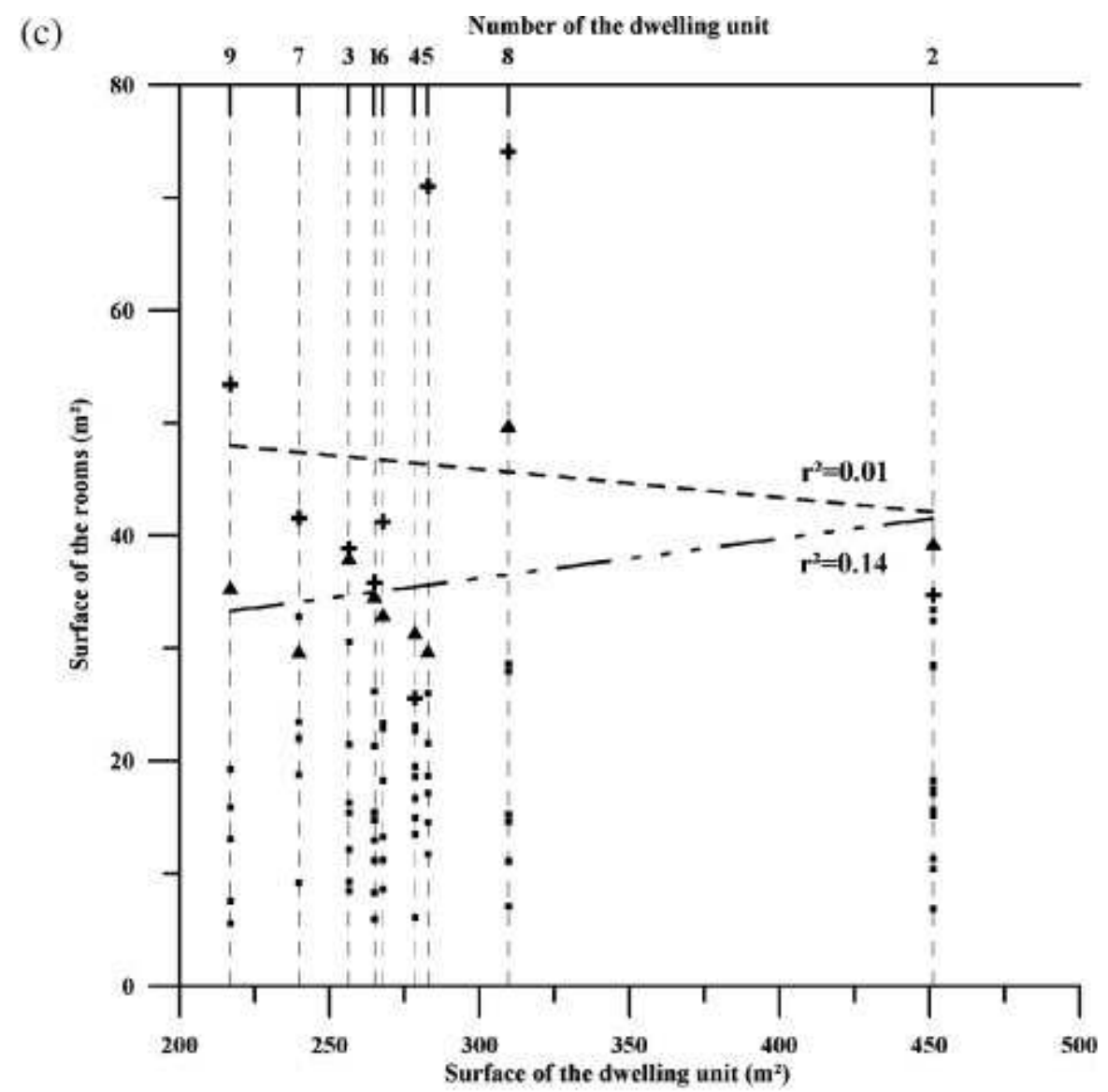

(d) Number of the dwelling unit

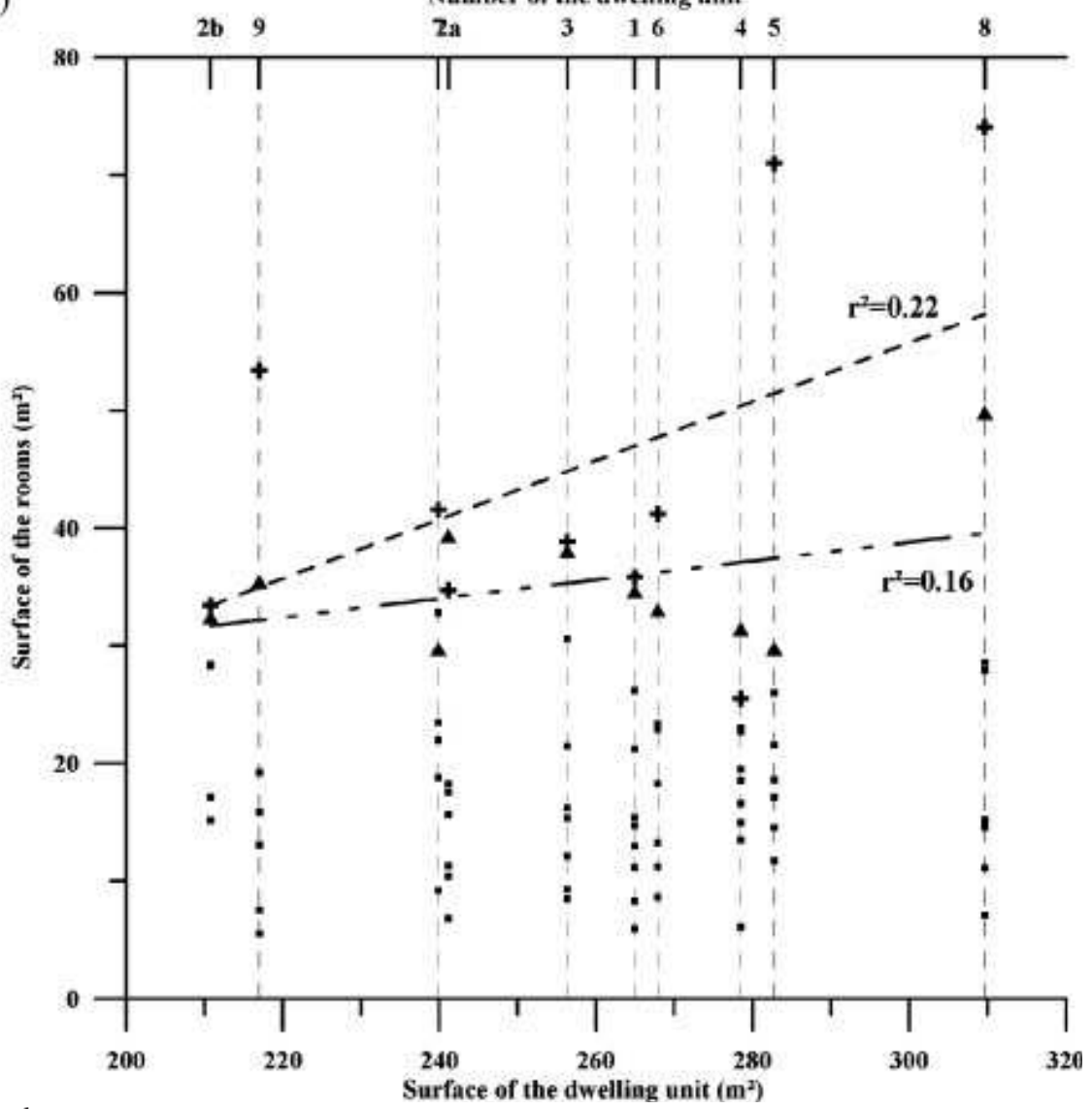

Figure 10. (Continued). 
The following are the important results for the interpretation of the geophysical map.

(i) The 'entrance-courtyard-reception room' layout is respected in all cases apart from units 7 and 9, where the entrance leads to a room instead of a corridor

ii) Generally there were four levels of depth, (number of steps that must be taken to arrive to the deepest room of the house starting from the entrance), whatever the size of the dwelling unit; and at times even a fifth level.

(iii) The main difference is the number of rooms around the courtyard, which increases with the size of the dwelling unit (see e.g. units 2 and 4 , Figure 7).

(iv) In most cases the rooms are distributed on three sides of the courtyard. In unit 12, a reception room was lacking. Of a total of 11 reception rooms, six were located in the southern part of the dwelling unit and open to the north.

Figure 10 compares the surface area of individual rooms against the surface area of the dwelling. Except in unit 9, where the identification of the reception room is uncertain, the courtyard and the reception room are the largest rooms of the houses. The reception room is generally larger than the courtyard, and the more important the house, the greater the increase in surface area of these two rooms. On the other hand, the mean surface area of the other rooms is almost the same for all dwelling units. Figure 11 demonstrates the importance of the courtyard and the reception room to domestic life: even in the smallest dwelling unit, number 3, more than $80 \%$ of the total surface area is used for these two rooms.

This study is admittedly limited to only one block, but these first results highlight certain interesting social and cultural aspects of the domestic dwelling. It can be assumed that the size of the dwelling unit was proportional to the richness of the occupier, as proved by excavation. Most dwelling units have a surface area of about $200 \mathrm{~m}^{2}$, i.e. less than the original $1 / 8$ division (306.25 $\mathrm{m}^{2}$ ). Unit 9 is the only one to have a surface area $>300 \mathrm{~m}^{2}$. The courtyard and the reception room were the most important places within the houses. These spaces were the parts of the house a visitor was likely to see, and it was therefore important to enhance them with exterior signs of richness and prestige. Another surprising result is that the other rooms have almost the same surface area, whatever the size of the dwelling unit. Only the number of rooms increased with the size of the dwelling unit. This tendency seems to show that whatever the social class (probably linked to a certain form of richness allowing an individual to have a bigger house), the inhabitants did not feel the necessity to live in larger rooms: private spaces had more or less the same dimensions.

Block C7 demonstrates an important diversity in the richness and size of its dwelling units, but this may be relative, as all of the proprietors may have belonged to the same cultural class and had the same social origin. These are only preliminary results of an approach applied for the first time to the households in DouraEuropos and therefore must be treated with with prudence until they are confirmed by excavation and survey.

\section{CASE STUDY II: BLOCK M2}

The general rectangular shape of block M2 and its dimensions hardly changed with time and remain close to the reference model (Figure $12)$; - although its subdivision into eight units is no longer visible for most of the last stage of its occupation. The lengthwise division can still be observed for the whole length of the block even if the wall does not look continuous. The transverse middle division continues to be visible but no longer seems to function as a separation between dwelling units any more (see below). The field survey map produced by 


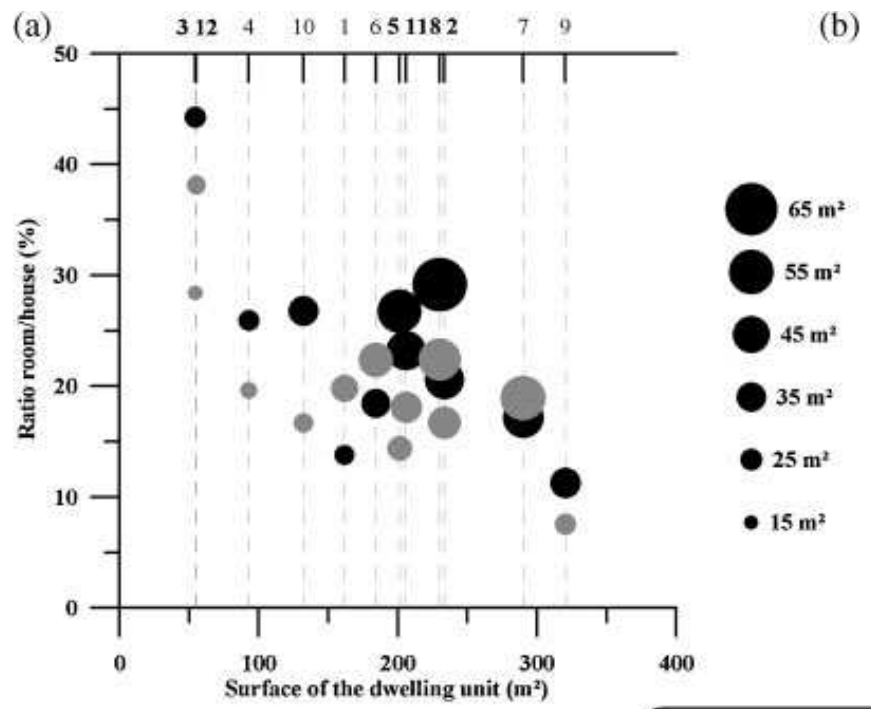

Block C7 (b)

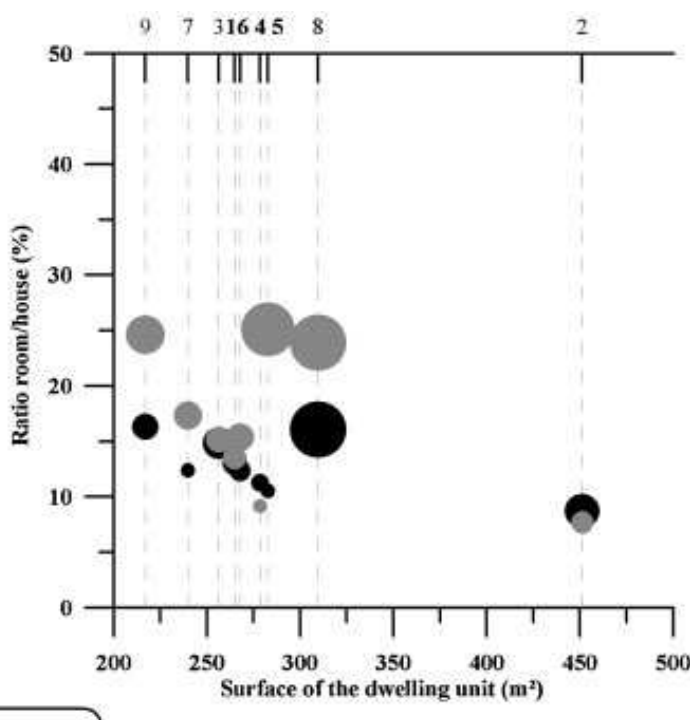

Block M2

Figure 11. Ratio of the surface room/house: (a) block C7; (b) blockM2.

the Yale expedition indicates 11 entrances for block M2: three were located on the western side of the block, one on its southern side and seven on its eastern side. All of these entrances are visible on the magnetic map. The widest of the streets surrounding the block is located along its eastern side, which also has the most entrances, and we can make the same observation as in the case of block C7: an increase in the number of entrances on one side of a block (mainly due to the presence of shops) is linked to the width of the streets.

The next step is to delimit the spaces inside the block: as previously stated, the most important aspect is to identify the different spaces, and uncertainty about the geometry or the exact surface area of the space does not affect the study (Figure 12c). The block is accordingly divided into 83 space units. Here, as with block $\mathrm{C} 7$, the courtyard and the reception room were the widest rooms of the house. Figure $12 \mathrm{~d}$ categorizes rooms with a surface area greater than $25 \mathrm{~m}^{2}$ : the logical position of the courtyard and the reception room are thereby easily identified. It is now possible to hypothesize the delimitation of the different dwelling units based on the observations of the space syntax schemes of block C7. Thus nine dwelling units can be delimited: four on the eastern and five on the western side. In the southern part of the block, plans of houses 3, 4, 5 and 6 are clearly visible with the classic organization observed in Doura-Europos; units 3 and 4 therefore have two entrances. The northern part of the block is more problematic because it has been subject to important transformations in the organization of space. Nonetheless, the identification of the courtyards and reception rooms allows units 7 , 8 and 9 to be delimited. In this hypothesis, only the entrance of unit 8 is not visible on the magnetic map and is not mentioned on the Yale map; the corridor between the supposed entrance and the courtyard is nevertheless clearly visible.

Units 1 and 2 are more complex because of the number of their three entrances and their location. The entrance, the courtyard and the reception room of unit 1 are clearly identified, but its boundary with unit 2 is rather unclear; it has to be located on the line of the southern wall of the reception room, because the northern entrance of unit 2 is immediately to the south. This dwelling unit therefore has two entrances, and it is in fact the widest of the block with four rooms with a surface area greater than $30 \mathrm{~m}^{2}$. Either a large dwelling unit 
(a)

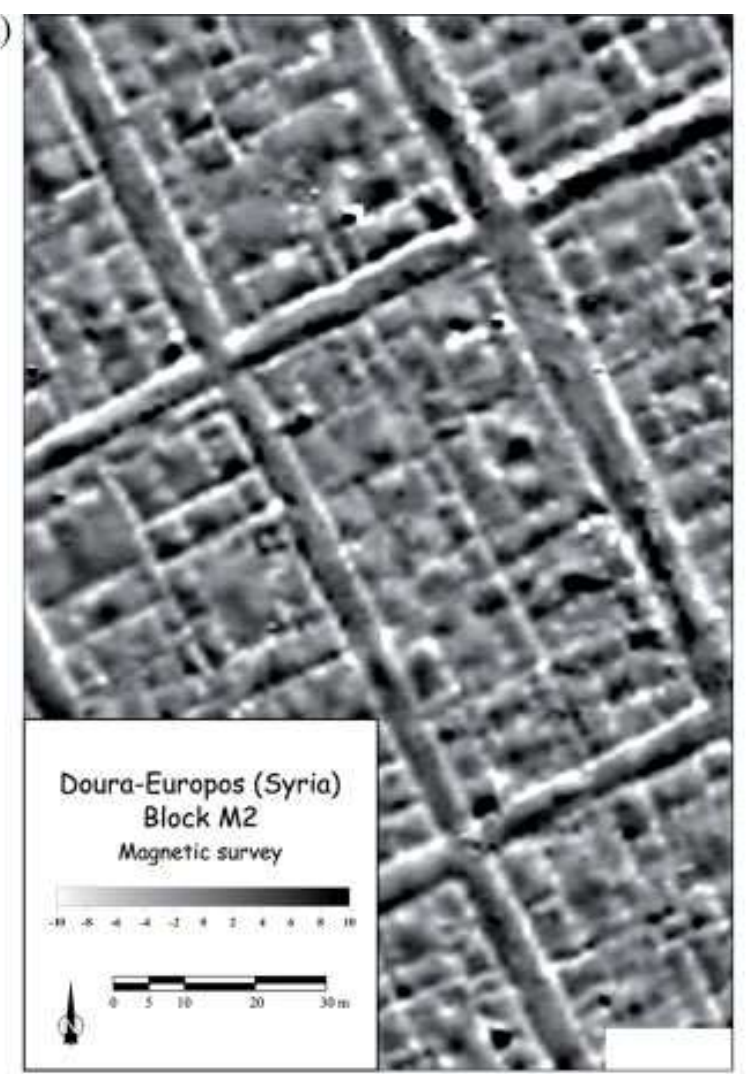

(c)

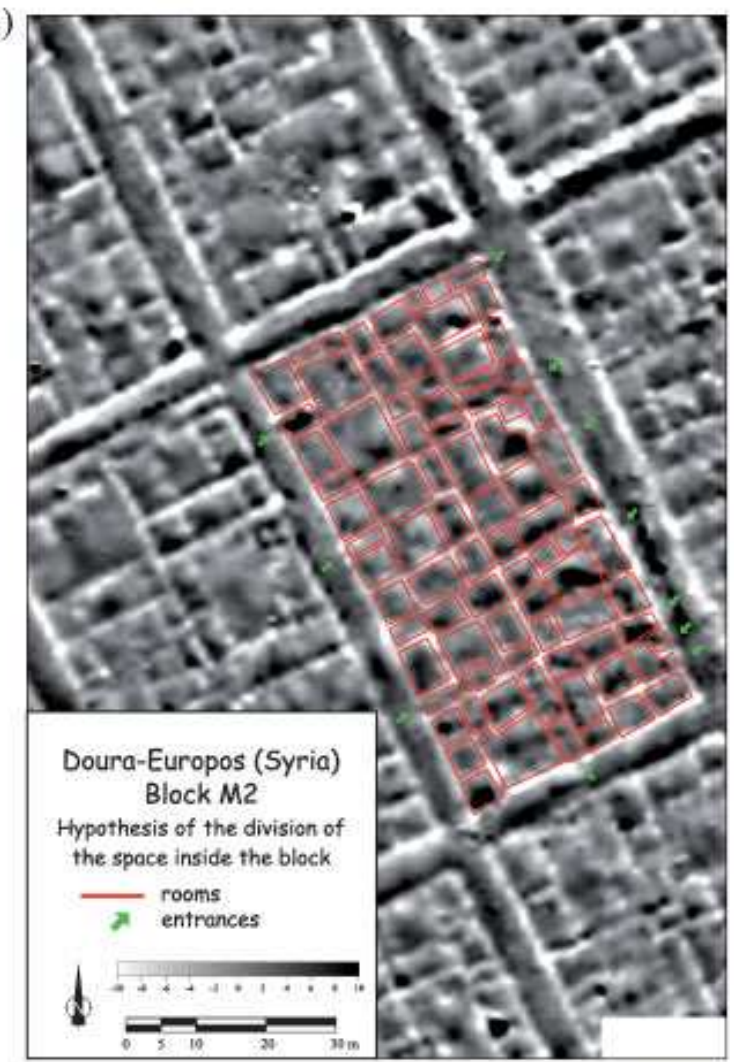

(b)

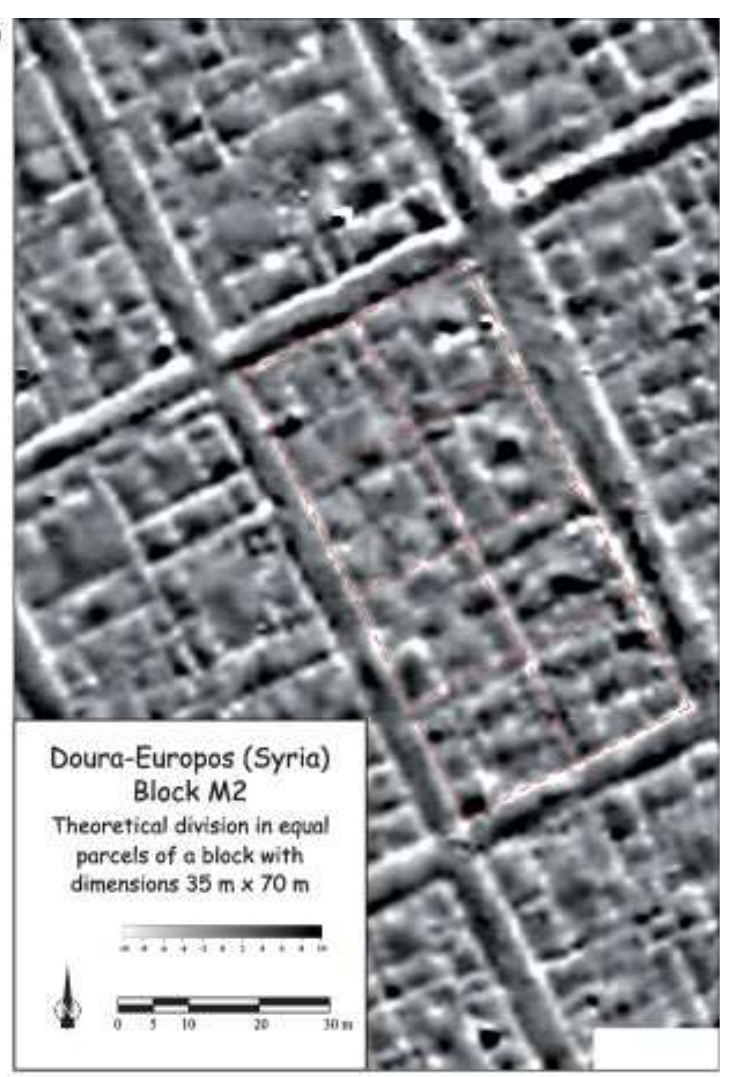

(d)

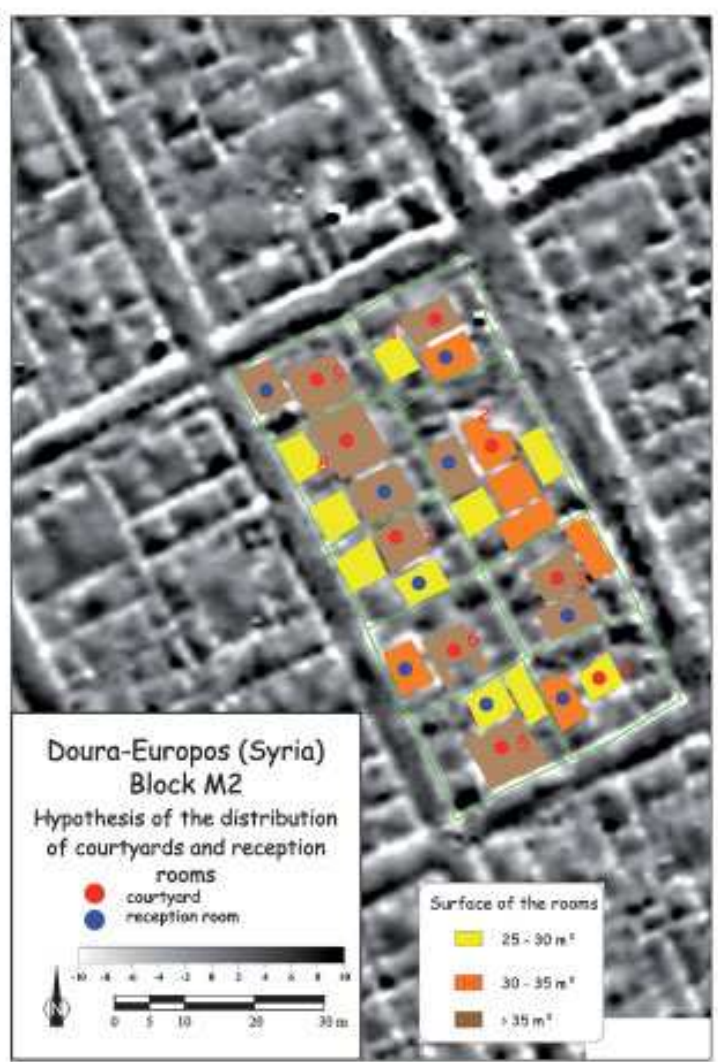

Figure 12. (a) Magnetic map of block M2. (b) Theoretical division in equal parcels of a block with dimensions 35m_70m. (c) Hypothesized division of the space inside the block. (d) Hypothesized distribution of the courtyards and reception rooms. 

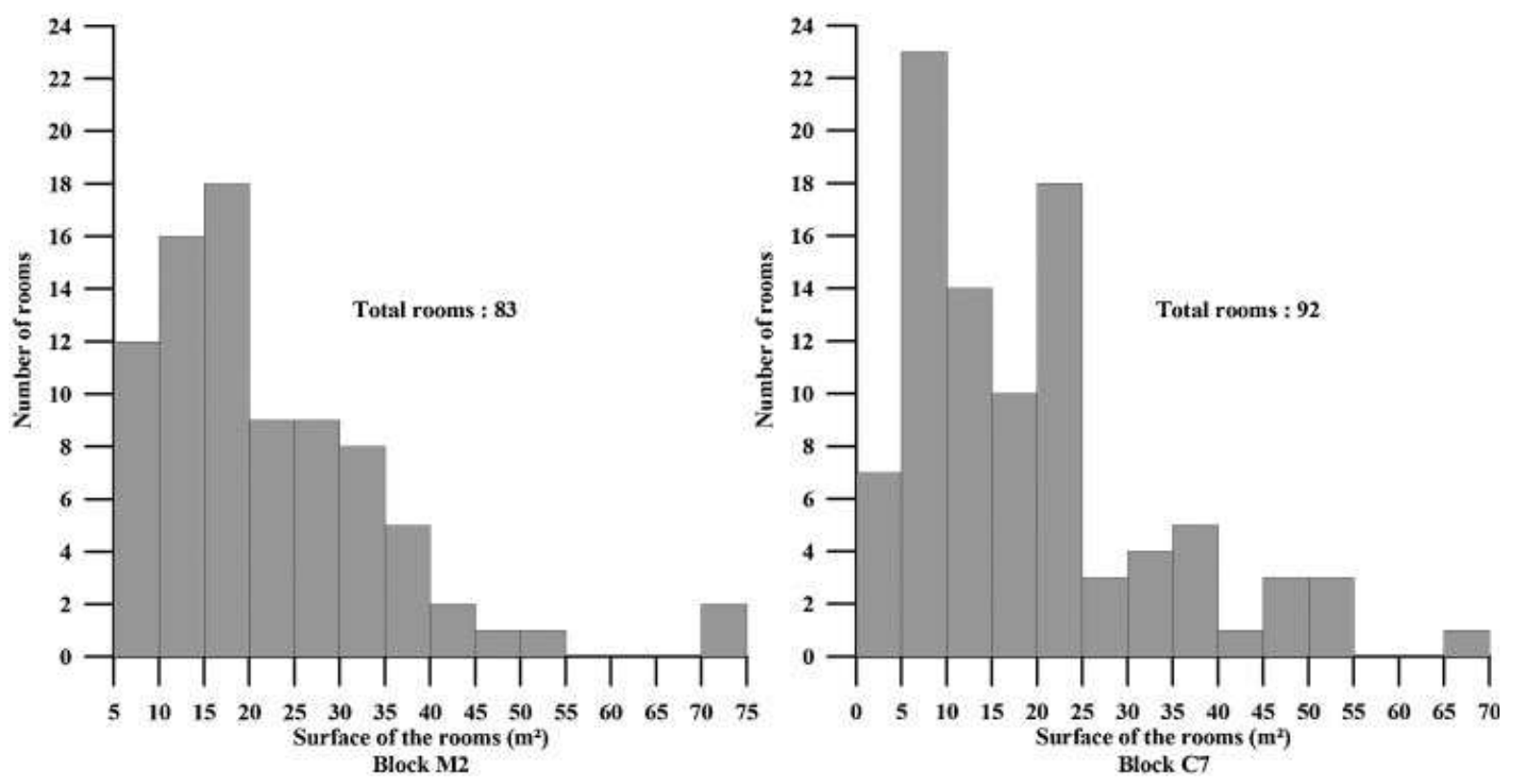

Figure 13. Histogram of the surface area of the rooms in blocks C7 and M2.

existed here - including an independent entrance for a shop - or this area represents two houses. In the latter case the southern house would not have an entrance corridor but a direct access to a room of more than $25 \mathrm{~m}^{2}$.

\section{DISCUSSION}

Even though it is not possible to draw definitive conclusions about the use of domestic space in Doura-Europos based on the study of only two blocks, it is interesting to compare the results obtained in both cases.

It was concluded that block M2 is made up of nine dwelling units compared with 12 dwelling units in block C7. The dwelling units accordingly were widest in M2, with the minimum surface area for dwelling units of M2 being $>200 \mathrm{~m}^{2}$.In contrast there are six dwelling units in $\mathrm{C} 7$ with a surface of $<200 \mathrm{~m}$. A histogram of the surface area of the rooms (Figure 13) shows that there were more smallsize rooms in C7, but the global distribution of the surface is the same for both blocks.
A graph of the distribution of the surface area of the rooms for each dwelling unit in M2 produces a different result (Figure 10c).

In block M2 the mean surface area of the courtyards is greater than that of the reception rooms. The linear regression line decreases in the case of the courtyard, which is attributable to the size of unit 2. This leads to two possibilities:

(i) there are two houses, as hinted at above;

(ii) unit 2 partly or entirely comprises an administrative or, more probably, a religious building. The latter is commonly seen in DouraEuropos. Many houses were transformed into religious buildings, whereby they maintain some characteristics of the domestic space, but their widest rooms have been transformed to receive the public. If unit 2 is divided into $2 \mathrm{a}$ and $2 \mathrm{~b}$ (Figure 10d), a closer correlation between M2 and C7 is evident, even if the coefficient of determination for M2 $\left(r^{2}=0.22\right)$ is very inferior to that of $\mathrm{C} 7\left(\mathrm{r}^{2}=0.44\right.$, or 0.83 if 
unit 9, which is a doubtful case, is not taken into account). As for the courtyard, the correlation between the reception room and the size of the dwelling unit is less evident in the case of M2 $\left(r^{2}=0.16\right)$ than for $\mathrm{C} 7\left(\mathrm{r}^{2}=0.35\right.$, or 0.59 without unit 9$)$.

The correlation between the courtyards, reception rooms and the dwelling unit size is less clear in the case of M2 even if the proportion of surface dedicated to both these rooms is almost the same (Figure 11b). Nevertheless it must be noted that the dwelling units of M2 are on average larger than those of $\mathrm{C} 7$, and the correlation observed in $\mathrm{C} 7$ is not the same for very large dwelling units, such as unit 2 in M2 and unit 9 in $\mathrm{C} 7$.

\section{CONCLUSIONS}

The results presented here show that an interpretative 'space syntax' approach adapted to the specific of geophysical data can open rich new avenues of research that are inaccessible by the common methods used in archaeology. The results presented here are, of course, partial, but they show how useful the study of space may be for the interpretation of geophysical maps, and at the same time the potential for developing such an approach in archaeology. A complete study would involve taking into account all excavated and surveyed dwelling units of Doura-Europos and the layout of streets in order to obtain a concerted vision of the organization of the public and private space of the city. From this point on, it will be possible to study the social and cultural aspects in relation to the use of space, at the level of not only the domestic unit but also of the city. Such an approach will considerably modify the study of city planning and will demonstrate that the role of the geophysical map is not only to offer a 'global view' for locating new places to excavate.
REFERENCES

Allison, P. (ed.) 1999. Dwelling in the Past: the Archaeology of Household Activities. London, Routledge.

Becker H., Faßbinder J., Jansen H. G. 1993. Magnetische Prospektion in der Untersiedlung von Troia, StudiaTroica 3:117-134.

Benech C. 2003. The study of ancient city planning by geophysical methods: the case of Doura-Europos, Syria. $5^{\text {th }}$ International Conference on Archaeological Prospection, Archaeologia Polona 40: 124-127.

Bourdieu, P. 2000. La maison ou le monde renversé. In Esquisse d'une théorie de la pratique, précédé de trois études d'ethnologie kabyle, Seuil : Paris: 61-82.

Cahill N. 2002. Household and city organization at Olynthus. Yale University Press: New Haven. - London.

Gaborit J., Leriche P., Benech C. 1999. Apamée. In Abadie-Reynal C. et al., Zeugmamoyenne vallée de l'Euphrate: rapport préliminaire de la campagne de fouille 1998. Anatolia Antiqua, 7: 334-347.

Gaffney C, Gater J. 2005. Project specifications or guidelines in commercial archaeological geophysics: a recipe for disaster? $6^{\text {th }}$ International Conference on Archaeological Prospection, September 14-17 2005, Roma, Italy: 220-222.

Grahame M. 1997. Public and private in the Roman house: the spatial order of the Casa del Fauno. In Laurence R., Wallace-Hadrill A. (ed.) 1997. Domestic space in the Roman world: Pompeii and beyond. Journal of Roman Archaeology: sup. 22, Portsmouth, RI: 137164. 
Groh S., Neubauer W., Seren S., EderHinterleitner A., Löcker K. 2002. Geophysikalische Messungen im NordÖstlichen Stadtteil von Flavia Solva: Interpretation und archäologische-historische

Jahreshefte des Österreichischen archäologischen Institutes in Wien Band 71: 79 132.

Groh S. 2003. Integrated prospection in the upper town of Ephesus, Turkey - a case study, $5^{\text {th }}$ International Conference on Archaeological Prospection, Archaeologia Polona 40: 185.

Hesse A. 1970. Introduction géophysique et notes techniques, in J. Vercoutter, Mirgissa I, Librairie Orientaliste P. Geuthner, Paris: 51 122.

Hesse A. 1999. Les dix commandements du bon petit prospecteur en archéologie, Bulletin $\mathrm{du}$ Centre Interdisciplinaire de Recherches Aériennes, 22, $4^{\text {ème }}$ trimestre: 89-90.

(english translation: Hesse A. 1999. The ten commandments of the genuine surveyor in archaeology, $3^{\mathrm{d}}$ International conference on archaeological prospection, Münich, 9-11 september 1999: 40.)

Hilllier B., Hanson J. 1984 The social logic of space. Cambridge University Press: Cambridge.

Hodder I., Orton C. 1976. Spatial analysis in archaeology. Cambridge university press: Cambridge - New York - Melbourne.

Hoepfner W., Schwander E.-L. 1986. Haus und Stadt im klassischen Griechenland. Deutsher Kunstverl: München.

Hopkins, C. 1934. The houses. In Rostovtzeff, M.I. (ed.). The Excavations at Dura Europos. Preliminary Report of the Fifth Season of Work, October 1931-March 1932. Yale University Press: New Haven: 34-46.
Jameson M. H. 1990 Domestic space in the Greek City State. In Kent S. (ed.) 1990. Domestic architecture and the use of space: An interdisciplinary cross-cultural study. Cambridge University Press: Cambridge: 92113.

Kent S. (ed.) 1990a. Domestic architecture and the use of space: An interdisciplinary crosscultural study. Cambridge University Press: Cambridge.

Kent S. 1990b. Activity areas and architecture: an interdisciplinary view of the relationship between use of space and domestic built environments. In Kent S. (ed.) 1990. Domestic architecture and the use of space: An interdisciplinary cross-cultural study. Cambridge University Press: Cambridge: 1-8.

Laurence R., Wallace-Hadrill A. (ed.) 1997. Domestic space in the Roman world: Pompeii and beyond. Journal of Roman Archaeology: sup. 22, Portsmouth, RI.

Levi-Strauss C. 1993 Tristes tropiques. Coll. Terre Humaine, $2^{\text {nd }}$ ed. Plon: Paris.

Martin R. 1974. L'Urbanisme dans la Grèce Antique. 2nd éd., A. et J. Picard : Paris.

Neubauer W. 2004. GIS in Archaeology - the interface between Prospection and Excavation. Archaeological Prospection 11(3): 159-166.

Nevett L. C. 1999. House and Society in the Ancient Greek World. Cambridge University Press: Cambridge.

Parker Pearson M., Richards C. (ed) 1994. Architecture and order : approaches to social space. Routledge: London ; New York.

Rapoport A. 1972. Pour une anthropologie de la maison. Dunod: Paris. 
Renfrew C. 1984. Approaches to social archaeology. Edinburgh University press, Edinburgh.

Rostovtzeff M. (ed.) 1939. The excavations at Dura-Europos. Preliminary Reports, Seventh and Eight Seasons, 1933-1934 and 1934-1935. Yale University Press: New Haven.

Saliou C. 1992. Les quatre fils de Polémocratès (P. Dura 19). Texte et archéologie. In Leriche P. (ed.) 1992. Doura-Europos Etudes III. Geuthner: Paris: 65-100.

Saliou C. 2005. La forme d'un îlot de DouraEuropos... L'îlot C7 revisité. In Leriche P., Gelin M., Dandrau A. (ed.) 2005. DouraEuropos Etudes V, Geuthner: Paris: 65-78.

Schmidt-Colinet A,. Plattner G. A. 2001. Geophysical survey and excavation in the "Hellenistic Town" of Palmyra. Archaeological prospection - 4th International Conference on Archaeological Prospection, Vienna 19.-23. September 2001: 175-177. 